\title{
Epidemiology of Chronic Kidney Disease and Associated Metabolic Risk Factors in an Old Chinese Population
}

\author{
Lingling Xu \\ Second Affiliated Hospital of Nanjing Medical University \\ Jin Liu \\ Second Affiliated Hospital of Nanjing Medical University \\ Aiqin He \\ Second Affiliated Hospital of Nanjing Medical University \\ Xiaomei Wu \\ Second Affiliated Hospital of Nanjing Medical University \\ Dongling Li \\ Department of Nephrology, People's Hospital of Binhai County, Jiangsu \\ Hua Yang \\ Department of Nephrology, People's Hospital of Binhai County, Jiangsu \\ Kechuan Shi \\ Department of Nephrology, People's Hospital of Binhai County, Jiangsu \\ Xian Wu \\ Department of Nephrology, People's Hospital of Binhai County, Jiangsu \\ Yang Zhou \\ Second Affiliated Hospital of Nanjing Medical University \\ Junwei Yang ( $\nabla$ jwyang@njmu.edu.cn ) \\ Second Affiliated Hospital of Nanjing Medical University
}

\section{Research Article}

Keywords: CKD, worldwide, health, disease

Posted Date: November 30th, 2020

DOI: https://doi.org/10.21203/rs.3.rs-107910/v1

License: (c) (1) This work is licensed under a Creative Commons Attribution 4.0 International License. Read Full License 


\section{Abstract}

Chronic kidney disease (CKD) has become a worldwide health problem among aging populations. However, epidemiological information on Chinese elderly people with CKD is still lacking. This study aimed to investigate the epidemiological features and associated risk factors of CKD in aging population in China. In this cross-sectional study, a total of 37,533 individuals aged $\geq 65$ years were enrolled in Binhai from January to December 2018. The crude and standardized prevalence of CKD were calculated. Associations of metabolism-related indicators with CKD were examined using univariate and multivariate analysis. The overall prevalence of CKD was $17.7 \%$ (95\% confidence interval [Cl], 17.3\%-18.1\%) in this Chinese elderly population. The prevalence was $17.5 \%$ among men $(95 \% \mathrm{Cl}, 17.0 \%-18.1 \%)$ and $17.8 \%$ among women $(95 \% \mathrm{Cl}, 17.3-18.4 \%)$. The mean eGFR was 84.22 (SD \pm 12.87) $\mathrm{mL} / \mathrm{min} / 1.73 \mathrm{~m}^{2}$, with the median value higher for women than for men. Aging, pre-HTN, HTN, elevated triglyceride and FBG were found to be independent risk factors for CKD. Our study shows a high prevalence of CKD among Chinese elderly population. Aging, pre-HTN, HTN, elevated triglyceride and FBG were all independent risk factors associated with CKD. More attention should be paid to metabolic diseases to prevent CKD in the elderly.

\section{Introduction}

Chronic kidney disease (CKD) emerges as a growing global public health problem. The prevalence of CKD is estimated to be 10$15 \%$ worldwide [1-5]. In 2017, 697.5 million cases of all-stage CKD were recorded, for a global prevalence of $9.1 \%$, and the all-age prevalence of CKD increased by 29.3\% from 1990 to 2017 [6]. Outcomes of CKD include not only progression to end-stage renal disease (ESRD) but also multiple associated complications leading to increased morbidity and mortality $[7,8]$.

The segment of the older population is growing rapidly worldwide. Older people are particularly susceptible to kidney damage from age-related decline in glomerular filtration and chronic disease states, such as diabetes mellitus and hypertension (HTN)[911]. The prevalence of CKD is significantly higher in the elderly than that in the general population. Even in developed district, the prevalence of CKD in the elderly is 14.7 to $21.4 \%$ [12-14]. Therefore, it is important to understand the epidemiological characteristics and associated risk factors of CKD in the elderly. However, few studies focused on the epidemiology and risk factors for CKD among the national elderly population in China.

In this study, we estimated the prevalence and stages of CKD in a large population aged 65 years and older in eastern China and assessed the association of CKD with related covariables.

\section{Results}

A total of 37533 individuals were included in the current analysis. The gender and age distribution of the participants aged $\geq 65$ years in our study was similar to that of the Chinese population in 2020 [15], with the sex ratio 1.08: 1 (female: male) in the general population and 1.07:1 in our study. The average age of the participants in our study was $73.76 \pm 5.49$ years (minimum 65 , maximum 104). The population in this analysis aged $65 \sim 74,75 \sim 84$ and $\geq 85$ years accounted for $63.3 \%, 31.7 \%$ and $5.0 \%$ respectively. The corresponding percentage was $62.3 \%, 31.3 \%$ and $6.4 \%$, respectively in the 2010 population census of China. Because of the high similarity in age and gender distribution between the elderly population in our study and the national elderly population, the findings of this study were representative.

We identified 6,636 (17.7\%) CKD cases. Table 1 shows the crude prevalence of CKD at different stages. Prevalence of stages 1, 2, 3 was at $7.5 \%, 4.5 \%$ and $5.4 \%$, respectively, and $0.3 \%$ of subjects had severe stage of CKD (stage 4 5). 2,160 (5.8\%) participants were classified as chronic renal insufficiency with decreased estimated glomerular filtration rate (eGFR). 4,997(13.3\%) cases had proteinuria, and 521 participants with reduced renal function accompanied by proteinuria (Table 1).

The crude prevalence of CKD in older adults in Binhai was 17.7\% (95\% Cl, 17.3\% 18.1\%). The prevalence was 17.5\% among men (95\% Cl, $17.0 \%-18.1 \%)$ and $17.8 \%$ among women (95\% Cl, 17.3\%-18.4\%). Furthermore, the age- and sex- standardized overall prevalence of CKD in Chinese older adults was $17.8 \%(95 \% \mathrm{Cl}, 17.4 \sim 18.2)$, with a rate of $18.1 \%(95 \% \mathrm{Cl}, 17.6 \sim 18.6)$ in women and $17.5 \%(95 \% \mathrm{Cl}, 17.0 \sim 18.1)$ in men (shown in Fig. 1). 
13.3\% (95\% Cl, 13.0\%-13.7\%) participants had proteinuria. In those with proteinuria, most of whom (87.2\%) had minimal amount (trace or one plus), outnumbering those with overt amount (two pluses or more) by 5.8-fold (shown in Fig. 2). There was no statistical difference in the prevalence of proteinuria in women and men $(13.2 \%$ vs $13.5 \%, p=0.403)$. Mean eGFR in this population was $84 \cdot 22(\mathrm{SD} \pm 12.87) \mathrm{mL} / \mathrm{min} / 1.73 \mathrm{~m}^{2}$, with the median value higher for women than for men (87.93 vs 87.21 $\mathrm{mL} / \mathrm{min} / 1.73 \mathrm{~m}^{2}$, shown in Fig. 3).

The prevalence of FBG $\geq 126 \mathrm{mg} / \mathrm{dl}$ and between $100 \sim 125 \mathrm{mg} / \mathrm{dl}$ in the elderly was $10.7 \%$ and $16.4 \%$, respectively. What's impressively was that 14515 (38.7\%) of the elderly in our study had HTN, and 19506 (52.0\%) participants had pre-HTN. This result is similar to that in elderly of China's hypertension survey in 2012-2015 [16]. Furthermore, the prevalence of overweight and obesity in the older adults was $35.9 \%$ and $5.5 \%$, respectively.

The participants who showed indicators of kidney damage were older, especially those with low eGFR. In addition, participants with low eGFR were more likely to be women, who had higher value of BMI, waist circumference, SBP, DBP, Heart rate, total cholesterol, triglycerides and FBG (Table 2). Among them, 34457 participants completed the blood routine test. It is remarkable that the hemoglobin concentration of patients with low eGFR is significantly lower than that of participants with proteinuria or non-renal injury group.

Considering the different clinical characteristics, participants with eGFR $<15 \mathrm{~mL} / \mathrm{min} / 1.73 \mathrm{~m}^{2}$ were excluded in the logistic regression Analysis. Univariate logistic regression models showed that the risk of CKD was correlated with the increase of age and metabolic related indicators such as obesity, central obesity, pre-HTN, HTN, increased FBG, elevated triglyceride and total cholesterol level. Gender was not a risk factor of CKD in the elderly. After adjusted with age, these indicators still showed similar results. Multivariate adjustment confirmed that aging, $\mathrm{HTN}, \mathrm{FBG} \geq 100 \mathrm{mg} / \mathrm{dL}$, triglyceride levels $\geq 2.26 \mathrm{mmol} / \mathrm{L}$ were found to be independent risk factors for CKD. In addition, the $p$-value for ORs of the association between pre-HTN, total cholesterol level $\geq 6.21 \mathrm{mmol} / \mathrm{L}$ and CKD were both less than 0.1 in the analysis (Table 3).

To further understand the relationship between these metabolic risk factors and CKD, we stratified these risk factors continuously and evaluated their change trend of age-adjusted ORs for CKD. Our study showed that patients with $\mathrm{BMI}<18 \mathrm{~kg} / \mathrm{m}^{2}$ and BMI $\geq$ $24 \mathrm{~kg} / \mathrm{m}^{2}$ had an increased risk of CKD after adjusted with age. The risk of CKD increased with the increase of BMI in the participants whose $B M I \geq 24 \mathrm{~kg} / \mathrm{m}^{2}$. In addition, the risk of CKD was positively correlated with systolic blood pressure, FBG and triglyceride (shown in Fig. 4).

We further grouped the population according to their FBG $(<100,100-125$, and $\geq 126 \mathrm{mg} / \mathrm{dL})$ and blood pressure (no-HTN, preHTN, and HTN). In subgroup analysis, this relationship was further confirmed. The effect of blood pressure and FBG on the prevalence of CKD demonstrated an enhancing effect. The prevalence of CKD increased significantly with the increase of FBG with normal blood pressure, the CKD prevalence rates in the three groups with gradually rising FBG were $14.5 \%, 17.5 \%$ and $21.3 \%$, respectively $(P<0.001)$. Furthermore, when the effect of HTN and pre-HTN were considered, the prevalence of CKD increased at each degree of FBG significantly. CKD was found in $28.6 \%$ of people with FBG $\geq 126 \mathrm{mg} / \mathrm{dL}$ and HTN (shown in Fig. 5a).

The Odds ratio for CKD is also associated with increasing level of FBG and the Classification of blood pressure in the elderly (shown in Fig. 5b). Compared with subjects with normal FBG and blood pressure, those with elevated blood glucose and blood pressure had significantly higher risk ORs of CKD.

\section{Discussion}

In our study, prevalence of CKD was $17.7 \%$ and gender was no longer a risk factor for CKD in the elderly. Furthermore, the prevalence of metabolic diseases is significantly high in this older population. Participants with lower eGFR were older, and more likely to be women, with higher value of BMI, waist circumference, SBP, DBP, heart rate, total cholesterol, triglycerides and FBG. Aging and metabolic disorders (HTN, FBG $\geq 100 \mathrm{mg} / \mathrm{dL}$, and triglyceride levels $\geq 2.26 \mathrm{mmol} / \mathrm{L}$ ) were found to be independent risk factors for CKD. In the subgroup analysis, strong correlations of CKD with elevated FBG and blood pressure were shown. 
The aging population is growing worldwide. Today, more than 600 million people are $\geq 65$ years old; the number will reach 1.6 billion in 2050- nearly $20 \%$ of the world's population [17]. Population aging affects both developed and developing countries[18]. In China, statistics from the national population census showed that the elderly accounted for $7.0 \%$ of the total population in 2000 , but it rose to $8.9 \%$ in $2010[15]$. It is predicted that there will be 400 million Chinese citizens aged $\geq 65$ years in 2050[19].

Aging is one of the major risk factors for multiple Chronic non-communicable diseases (CNCDs), such as diabetes mellitus, HTN and obesity[20-22]. In recent years, with the rapid economic development and associated dramatic lifestyle changes, the prevalence of CNCDs in China has increased significantly[23]. In a large-scale population-based survey conducted in 2013 in mainland China, the estimated standardized prevalence of diabetes and pre-diabetes were $10.9 \%$ and $35.7 \%$, respectively. It is remarkable that $20.2 \%$ and $45.8 \%$ of people aged $\geq 60$ years were estimated to have diabetes and pre-diabetes[23]. Another nationwide survey conducted between October 2012 and December 2015 indicated that $23.2 \%$ (244.5 million) of Chinese people $\geq 18$ years of age had HTN, and $41.3 \%$ (435.3million) had pre-HTN. Furthermore, the study also showed that the prevalence of HTN was $>55 \%$ among citizens aged $\geq 65$ years[16]. Obesity has also become one of most important CNCDs affecting the health of Chinese adults during the past decade. In 2012, prevalence of obesity and overweight ( $\geqslant 18$ years) was 11.9 and $30.1 \%$, compared with 7.1 and $22.8 \%$ in 2002 , respectively[24, 25].

Meanwhile, many studies have confirmed that CNCDs play an important role in the development and progression of CKD, especially in the elderly. A community-based cohort of elderly individuals ( $\geq 65$ years) showed that the annual rate of eGFR decline in men and women without diabetes was 0.8 and $1.4 \mathrm{ml} / \mathrm{min} / 1.73 \mathrm{~m}^{2}$ respectively, which increased to 2.1 and 2.7 $\mathrm{mL} / \mathrm{min} / 1.73 \mathrm{~m}^{2}$ for individuals with diabetes. Michishita $\mathrm{R}$ et al. demonstrated that HTN may be associated with the incidence of CKD in middle-aged and older males[26]. Obesity has also become one of most important CNCDs affecting the health of Chinese adults during the past decade. The correlation between obesity and CKD has also been confirmed in previous studies.

Changes in the epidemiology of these CNCDs further affect the prevalence of CKD in general population, especially the elderly[27]. These results all suggested that CNCDs, especially metabolic diseases, should be paid more attention to in the elderly population. Our study also draws similar conclusions, the prevalence of CKD was increased with the increasing FBG and with HTN and pre-HTN. In addition, obesity and abnormal lipid metabolism are also independent risk factors for CKD[28-31]. Interestingly, our study also found that triglycerides, not cholesterol, remained an independent risk factor for CKD. It was reported that elevated triglyceride was significantly associated with a higher risk of arterial stiffness and nephric microvascular damage[32]. In addition to overweight, underweight was also significantly associated with increased risk of CKD. Several studies showed that Patients with $\mathrm{BMl}<18.5 \mathrm{~kg} / \mathrm{m}^{2}$ exhibited non-significantly higher events of eGFR decline events in both early and late CKD stages than other BMI groups[33]. It reminds us that CKD is a complex disease that requires individualized nutritional intervention to its treatment.

Unfortunately, even in developed countries, many studies shows that the awareness of CKD remains low due to long asymptomatic phase of CKD $[34,35]$. CKD is a disease that is amenable to screening. Better management can slow progression of renal dysfunction and multiple associated complications. Fortunately, China launched a health-care reform plan that pledged to provide all citizens with equal access to basic health care with reasonable quality and financial risk protection in 2009[36]. The local government has conducted annually universal free health examinations for residents in Binhai country since January 2017. It was then gradually integrated with information on population screening, public health surveillance, hospital health information systems, disease management, and other healthcare services.

This study has several limitations. First, this was a retrospective cross-sectional analysis, some information about the participants' social and demographic status, lifestyle, histories of cardiovascular disease, diabetes, and HTN, and nephrotoxic medication use was missing. Second, all covariates were obtained from single measurements; therefore, the reported prevalence of abnormal glucose metabolism, HTN, and pre-HTN might be biased. Furthermore, the relationship between risk factors and CKD needed further investigation in a cohort study rather than a cross-sectional study. Indeed, we will follow the current population of this study for several years. 
In conclusion, CKD is a highly prevalent condition with numerous health risks, and the estimated overall prevalence of CKD among Chinese older adults in 2018 was $17.7 \%$. The increasing prevalence of multi-metabolic diseases in an aging population would increase the prevalence of CKD and have a profound impact on China's social economy and public health. More attention should be paid to this part of the population. It is recommended that China's NCDs control strategy be strengthened to meet the demands of the aging population.

\section{Methods}

\section{Data sources and participants:}

Binhai is a district in Jiangsu province, located in the eastern coastal area of China. The per capital income of Binhai county residents was close to the national average in 2018. Therefore, this region is representative both in geographical location and economy. Furthermore, it was selected because of its universal coverage of free primary care and an integrated electronic health information system. The annual health examination program offered by the local government for Binhai persistent residents is free. The data was extracted using stratified, multistage random sampling from the regional health information system. Finally, a total of 37533 individuals aged $\geq 65$ years in Binhai were enrolled in this study between $1^{\text {st }}$ January, 2018, and $31^{\text {st }}$ December, 2018.

\section{Study measurements and definitions:}

Urinary protein was measured from a fresh random spot urine sample stored at $4^{\circ} \mathrm{C}$ for less than 1 week. Proteinuria was assessed using the urine dipstick test and reported as negative, trace, $1+, 2+$, or $3+$. We defined proteinuria as trace or greater protein [37]. Blood was collected after an overnight fast of at least $10 \mathrm{~h}$. All blood and urine samples were analyzed at the central laboratory of Binhai Hospital. Serum creatinine was measured using the kinetic rate Jaffe's method, and eGFR was calculated by the CKD Epidemiology Collaboration creatinine equation (CKD-EPI). The CKD-EPI equation was calculated as GFR ( $\mathrm{mL} / \mathrm{min} / 1.73$

$\left.\mathrm{m}^{2}\right)=141 \times \min (\mathrm{Scr} / \mathrm{K}, 1)^{\mathrm{a}} \times \max (\mathrm{Scr} / \mathrm{K}, 1)^{-1.209} \times 0.993^{\mathrm{Age}} \times 1.018$ (if female) $\times 1.159$ (if Black), where Scr is standardized serum creatinine in $\mathrm{mg} / \mathrm{dl}$, $a$ is -0.329 for females and -0.411 for males, $k$ is 0.7 for females and 0.9 for males, min indicates the minimum of $\mathrm{Scr} / \mathrm{K}$ or 1 , and max indicates the maximum of $\mathrm{Scr} / \mathrm{K}$ or $1[38]$.

Reduced renal function was defined as eGFR less than $60 \mathrm{~mL} / \mathrm{min}$ per $1.73 \mathrm{~m}^{2}$. The CKD stages were categorized based on the classification system established by the National Kidney Foundation Kidney Disease Outcomes Quality Initiative [39]. The CKD stages are defined as follows: Stage 1, proteinuria with eGFR $\geq 90 \mathrm{~mL} / \mathrm{min} / 1.73 \mathrm{~m}^{2}$; Stage 2, proteinuria with eGFR of $60 \sim 89$ $\mathrm{mL} / \mathrm{min} / 1.73 \mathrm{~m}^{2}$; Stage 3, an eGFR of $30 \sim 59 \mathrm{~mL} / \mathrm{min} / 1.73 \mathrm{~m}^{2}$; Stage 4, an eGFR of $15 \sim 29 \mathrm{~mL} / \mathrm{min} / 1.73 \mathrm{~m}^{2}$; Stage 5, eGFR < $15 \mathrm{~mL} / \mathrm{min} / 1.73 \mathrm{~m}^{2}$. Furthermore, patients in Stage 3 can be subdivided as follows: Stage 3a, an eGFR of $45 \sim 59 \mathrm{~mL} / \mathrm{min} / 1.73$ $\mathrm{m}^{2}$; Stage $3 \mathrm{~b}$, an eGFR of $30 \sim 44 \mathrm{~mL} / \mathrm{min} / 1.73 \mathrm{~m}^{2}$.

\section{Assessment of Possible Risk Factors!}

We defined central obesity based on a waist circumference greater than $90 \mathrm{~cm}$ for men or $80 \mathrm{~cm}$ for women [40]. BMI was calculated as weight in kilograms divided by height in meters squared $\left(\mathrm{kg} / \mathrm{m}^{2}\right)$, obesity was defined as a BMl of $\geq 28.0 \mathrm{~kg} / \mathrm{m}^{2}$, and overweight was defined as a BMI between 24.0 and $27.9 \mathrm{~kg} / \mathrm{m}^{2}$ [41]. HTN was defined as a blood pressure of 140/90 mmHg or more, pre-HTN was defined as SBP between 120 and $139 \mathrm{mmHg}$, or DBP between 80 and $89 \mathrm{mmHg}$ [42]. According to the American Diabetes mellitus Association 2020 criteria, the baseline FBG level was categorized into the following three groups: $<100,100-125$, and $\geq 126 \mathrm{mg} / \mathrm{dL}$ [43].

\section{Statistical analysis}

All analyses were done with SPSS Statistics 19.0 (Chicago, IL, USA). Data was presented as the mean \pm SD for continuous variables and as proportions for categorical variables. ALT was presented as median with interquartile range (IQR), due to nonnormal distribution. Odds ratios (ORs) and prevalence were reported with 95\% confidence intervals (Cls). The prevalence was adjusted according to age and sex to represent the total population of elderly by the direct method with the 2010 distribution of 
the Chinese population [15]. We analyzed the association between CKD and relevant covariates with univariate and multivariate logistic regression models. In the logistic regression models, participants with eGFR $<15 \mathrm{~mL} / \mathrm{min} / 1.73 \mathrm{~m}^{2}$ were excluded because of different clinical characteristics. 3076 (8.20\%) of the study population lacked blood routine data, 466 (1.24\%) lacked $\mathrm{BMI}$ information, and the proportion of missing values for other variables was less than $0.1 \%$. Regression estimation was used to deal with the missing data. Two-tail t-test $p$-value $<0.05$ was considered statistically significant.

\section{Declarations}

\section{Acknowledgements:}

The investigators are grateful to all participants and their families for their commitment to this study.

\section{Statement of Ethics:}

The study protocol was approved by the Institutional Ethical Committee of the Nanjing Medical University. All analyses followed the Strengthening the Reporting of Observational Studies in Epidemiology (STROBE) guidelines. Informed consent was obtained from all study participants.

\section{Conflict of Interest Statement}

No conflicts of interest, financial or otherwise, are declared by the authors.

\section{Funding Sources}

The study is supported by the grants from National Natural Science Foundation of China: Key program 81530022 and General program 81873618 to Junwei Yang. Youth fund 81600526 to Yang Zhou. Jiangsu Province social development fund BE2017762 to Junwei Yang. Youth medical talent fund QNRC2016670 to Yang Zhou.

\section{Authors' Contributions}

J.Y, Y.Z. and X.W. conceived the study. L.X., J.L., D.L., H.Y, K.S., A.H. and X.W. were involved in clinical care of the participants and data acquisition. L.X. and Y.Z. were involved in analyzing the data and writing the initial draft of the manuscript., J.Y. J.L., D.L., H.Y, K.S., A.H. and X.W. were involved in editing and revision of the manuscript. All authors approved the final manuscript. J.Y. is the guarantor of this work and, as such, had full access to all the data in the study and takes responsibility for the integrity of the data and the accuracy of the data analysis.

\section{References}

1. Zhang L, Wang F, Wang L, Wang W, Liu B, Liu J, et al. Prevalence of chronic kidney disease in China: a cross-sectional survey. Lancet. 2012;379(9818):815-22.

2. Coresh J, Selvin E, Stevens LA, Manzi J, Kusek JW, Eggers P, et al. Prevalence of chronic kidney disease in the United States. Jama. 2007;298(17):2038-47.

3. Murphy D, McCulloch CE, Lin F, Banerjee T, Bragg-Gresham JL, Eberhardt MS, et al. Trends in Prevalence of Chronic Kidney Disease in the United States. Annals of internal medicine. 2016;165(7):473-81.

4. Hill NR, Fatoba ST, Oke JL, Hirst JA, O'Callaghan CA, Lasserson DS, et al. Global Prevalence of Chronic Kidney Disease - A Systematic Review and Meta-Analysis. PloS one. 2016;11(7):e0158765.

5. Mills KT, Xu Y, Zhang W, Bundy JD, Chen CS, Kelly TN, et al. A systematic analysis of worldwide population-based data on the global burden of chronic kidney disease in 2010. Kidney international. 2015;88(5):950-7.

6. Collaboration GBDCKD. Global, regional, and national burden of chronic kidney disease, 1990-2017: a systematic analysis for the Global Burden of Disease Study 2017. Lancet. 2020;395(10225):709-33. 
7. Hallan SI, Matsushita K, Sang Y, Mahmoodi BK, Black C, Ishani A, et al. Age and association of kidney measures with mortality and end-stage renal disease. Jama. 2012;308(22):2349-60.

8. Chronic Kidney Disease Prognosis C, Matsushita K, van der Velde M, Astor BC, Woodward M, Levey AS, et al. Association of estimated glomerular filtration rate and albuminuria with all-cause and cardiovascular mortality in general population cohorts: a collaborative meta-analysis. Lancet. 2010;375(9731):2073-81.

9. Coresh J, Astor BC, Greene T, Eknoyan G, Levey AS. Prevalence of chronic kidney disease and decreased kidney function in the adult US population: Third National Health and Nutrition Examination Survey. American journal of kidney diseases : the official journal of the National Kidney Foundation. 2003;41(1):1-12.

10. Hemmelgarn BR, Zhang J, Manns BJ, Tonelli M, Larsen E, Ghali WA, et al. Progression of kidney dysfunction in the community-dwelling elderly. Kidney international. 2006;69(12):2155-61.

11. Rule AD, Amer H, Cornell LD, Taler SJ, Cosio FG, Kremers WK, et al. The association between age and nephrosclerosis on renal biopsy among healthy adults. Annals of internal medicine. 2010;152(9):561-7.

12. Konig M, Gollasch M, Demuth I, Steinhagen-Thiessen E. Prevalence of Impaired Kidney Function in the German Elderly: Results from the Berlin Aging Study II (BASE-II). Gerontology. 2017;63(3):201-9.

13. Amaral TLM, Amaral CA, Vasconcellos MTL, Monteiro GTR. Prevalence and factors associated to chronic kidney disease in older adults. Revista de saude publica. 2019;53:44.

14. Zhang QL, Koenig W, Raum E, Stegmaier C, Brenner H, Rothenbacher D. Epidemiology of chronic kidney disease: results from a population of older adults in Germany. Preventive medicine. 2009;48(2):122-7.

15. Tabulation on the 2010 population census of the people's republic of China. Available from: http://www.stats.gov.cn/tjsj/pcsj/rkpc/6rp/indexch.htm.

16. Wang Z, Chen Z, Zhang L, Wang X, Hao G, Zhang Z, et al. Status of Hypertension in China: Results From the China Hypertension Survey, 2012-2015. Circulation. 2018;137(22):2344-56.

17. Dzau VJ, Inouye SK, Rowe JW, Finkelman E, Yamada T. Enabling Healthful Aging for All - The National Academy of Medicine Grand Challenge in Healthy Longevity. The New England journal of medicine. 2019;381(18):1699-701.

18. Jha V, Garcia-Garcia G, Iseki K, Li Z, Naicker S, Plattner B, et al. Chronic kidney disease: global dimension and perspectives. Lancet. 2013;382(9888):260-72.

19. Fang EF, Scheibye-Knudsen M, Jahn HJ, Li J, Ling L, Guo H, et al. A research agenda for aging in China in the 21st century. Ageing research reviews. 2015;24(Pt B):197-205.

20. Xu Y, Wang L, He J, Bi Y, Li M, Wang T, et al. Prevalence and control of diabetes in Chinese adults. Jama. 2013;310(9):94859.

21. Xu G, Liu B, Sun Y, Du Y, Snetselaar LG, Hu FB, et al. Prevalence of diagnosed type 1 and type 2 diabetes among US adults in 2016 and 2017: population based study. Bmj. 2018;362:k1497.

22. Buford TW. Hypertension and aging. Ageing research reviews. 2016;26:96-111.

23. Wang L, Gao P, Zhang M, Huang Z, Zhang D, Deng Q, et al. Prevalence and Ethnic Pattern of Diabetes and Prediabetes in China in 2013. Jama. 2017;317(24):2515-23.

24. Li LM, Rao KQ, Kong LZ, Yao CH, Xiang HD, Zhai FY, et al. [A description on the Chinese national nutrition and health survey in 2002]. Zhonghua liu xing bing xue za zhi = Zhonghua liuxingbingxue zazhi. 2005;26(7):478-84.

25. Report on nutrition and chronic diseases of Chinese residents (2015). Available from: http://www.nhc.gov.cn/jkj/s5879/201506/4505528e65f3460fb88685081ff158a2.shtml.

26. Michishita R, Matsuda T, Kawakami S, Tanaka S, Kiyonaga A, Tanaka H, et al. Hypertension and hyperglycemia and the combination thereof enhances the incidence of chronic kidney disease (CKD) in middle-aged and older males. Clinical and experimental hypertension. 2017;39(7):645-54.

27. de Boer IH, Katz R, Fried LF, Ix JH, Luchsinger J, Sarnak MJ, et al. Obesity and change in estimated GFR among older adults. American journal of kidney diseases : the official journal of the National Kidney Foundation. 2009;54(6):1043-51. 
28. Qiu Y, Zhao Q, Gu Y, Wang N, Yu Y, Wang R, et al. Association of Metabolic Syndrome and Its Components with Decreased Estimated Glomerular Filtration Rate in Adults. Annals of nutrition \& metabolism. 2019;75(3):168-78.

29. Saland JM, Kupferman JC, Pierce CB, Flynn JT, Mitsnefes MM, Warady BA, et al. Change in Dyslipidemia with Declining Glomerular Filtration Rate and Increasing Proteinuria in Children with CKD. Clinical journal of the American Society of Nephrology : CJASN. 2019;14(12):1711-8.

30. Yun HR, Kim H, Park JT, Chang TI, Yoo TH, Kang SW, et al. Obesity, Metabolic Abnormality, and Progression of CKD. American journal of kidney diseases : the official journal of the National Kidney Foundation. 2018;72(3):400-10.

31. Garofalo C, Borrelli S, Minutolo R, Chiodini P, De Nicola L, Conte G. A systematic review and meta-analysis suggests obesity predicts onset of chronic kidney disease in the general population. Kidney international. 2017;91(5):1224-35.

32. Zhao S, Yu S, Chi C, Fan X, Tang J, Ji H, et al. Association between macro- and microvascular damage and the triglyceride glucose index in community-dwelling elderly individuals: the Northern Shanghai Study. Cardiovascular diabetology. 2019;18(1):95.

33. Chang TJ, Zheng CM, Wu MY, Chen TT, Wu YC, Wu YL, et al. Relationship between body mass index and renal function deterioration among the Taiwanese chronic kidney disease population. Scientific reports. 2018;8(1):6908.

34. Tuot DS, Plantinga LC, Hsu CY, Jordan R, Burrows NR, Hedgeman E, et al. Chronic kidney disease awareness among individuals with clinical markers of kidney dysfunction. Clinical journal of the American Society of Nephrology : CJASN. 2011;6(8):1838-44.

35. Coresh J, Byrd-Holt D, Astor BC, Briggs JP, Eggers PW, Lacher DA, et al. Chronic kidney disease awareness, prevalence, and trends among U.S. adults, 1999 to 2000. Journal of the American Society of Nephrology : JASN. 2005;16(1):180-8.

36. Yip WC, Hsiao WC, Chen W, Hu S, Ma J, Maynard A. Early appraisal of China's huge and complex health-care reforms. Lancet. 2012;379(9818):833-42.

37. Wen CP, Yang YC, Tsai MK, Wen SF. Urine dipstick to detect trace proteinuria: an underused tool for an underappreciated risk marker. American journal of kidney diseases : the official journal of the National Kidney Foundation. 2011;58(1):1-3.

38. Levey AS, Stevens LA, Schmid CH, Zhang YL, Castro AF, 3rd, Feldman HI, et al. A new equation to estimate glomerular filtration rate. Annals of internal medicine. 2009;150(9):604-12.

39. National Kidney F. K/DOQI clinical practice guidelines for chronic kidney disease: evaluation, classification, and stratification. American journal of kidney diseases : the official journal of the National Kidney Foundation. 2002;39(2 Suppl 1):S1-266.

40. Alberti KG, Zimmet P, Shaw J, Group IDFETFC. The metabolic syndrome-a new worldwide definition. Lancet. 2005;366(9491):1059-62.

41. Zhou BF, Cooperative Meta-Analysis Group of the Working Group on Obesity in C. Predictive values of body mass index and waist circumference for risk factors of certain related diseases in Chinese adults-study on optimal cut-off points of body mass index and waist circumference in Chinese adults. Biomedical and environmental sciences : BES. 2002;15(1):83-96.

42. Weber MA, Schiffrin EL, White WB, Mann S, Lindholm LH, Kenerson JG, et al. Clinical practice guidelines for the management of hypertension in the community a statement by the American Society of Hypertension and the International Society of Hypertension. Journal of hypertension. 2014;32(1):3-15.

43. American Diabetes A. 2. Classification and Diagnosis of Diabetes: Standards of Medical Care in Diabetes-2020. Diabetes care. 2020;43(Suppl 1):S14-S31.

\section{Tables}

Table 1: Prevalence of indicators of kidney function, by disease stage 


\begin{tabular}{|c|c|c|c|c|c|c|}
\hline & \multicolumn{3}{|l|}{ Kidney function } & \multicolumn{2}{|c|}{ Proteinuria } & \multirow{3}{*}{$\begin{array}{l}\text { CKD } \\
\text { Prevalence } \\
\square \%, 95 \% \mathrm{CI} \square\end{array}$} \\
\hline & eGFR (mL/min & $\mathbf{n}$ & Prevalence & $\mathbf{n}$ & Prevalence & \\
\hline & & & $\mathrm{\square} \%, 95 \% \mathrm{Cl}$ & & $\mathrm{\square} \%, 95 \% \mathrm{Cl}]$ & \\
\hline 1 & $\geq 90$ & 14087 & $37.5 \varangle 37.1 \sim 38.0 \rrbracket$ & 2797 & 19.9ه19.2 20.5区 & 7.5ه7.2 7.7凶 \\
\hline 2 & $60 \sim 89$ & 21286 & $56.7 \llbracket 56.2 \sim 57.2 \rrbracket$ & 1679 & $7.9 \otimes 7.5 \sim 8.2 \rrbracket$ & $4.5 \rrbracket 4.3 \sim 4.7 \rrbracket$ \\
\hline 3 & $30 \sim 59$ & 2039 & $5.4 \rrbracket 5.2 \sim 5.7 \rrbracket$ & 438 & 21.5ه19.8 23.3》 & $5.4 \bigotimes 5.2 \sim 5.7 \rrbracket$ \\
\hline $3 a$ & $45 \sim 59$ & 1644 & $4.4 \rrbracket 4.2 \sim 4.6 \rrbracket$ & 220 & 13.4冈11.8 15.0》 & $4.4 ه 4.2 \sim 4.6 \rrbracket$ \\
\hline $3 b$ & $30 \sim 44$ & 395 & $1.1 \otimes 1.0 \sim 1.2 \rrbracket$ & 218 & $55.2 \varangle 50.5 \sim 60.2 \rrbracket$ & $1.1 \otimes 0.9 \sim 1.2 \rrbracket$ \\
\hline 4 & $15 \sim 29$ & 86 & $0.2 \varangle 0.2 \sim 0.3 \rrbracket$ & 57 & $66.3 \rrbracket 55.8 \sim 76.2 \rrbracket$ & $0.2 \varangle 0.2 \sim 0.3 \rrbracket$ \\
\hline 5 & $<15$ & 35 & $0.1 \varangle 0.1 \sim 0.1 \otimes$ & 26 & 74.3凶58.8 88.2】 & $0.1 \varangle 0.1 \sim 0.1 \rrbracket$ \\
\hline Total & & 37533 & 100.0 & 4997 & 13.3凶13.0 13.7》 & 17.7ه17.3 18.1ه \\
\hline
\end{tabular}

Proteinuria was defined as trace or greater protein.

CKD was defined as eGFR $<60 \mathrm{~mL} / \mathrm{min}$ per $1 \cdot 73 \mathrm{~m}^{2}$ or Proteinuria. eGFR=estimated glomerular filtration rate. CKD=chronic kidney disease. $95 \% \mathrm{Cl}, 95 \%$ confidence interval.

Table 2ロGeneral Characteristics of Study Participants according to indicators of kidney damage 


\begin{tabular}{|c|c|c|c|c|}
\hline & $\begin{array}{l}\text { Participants with no } \\
\text { indicators of kidney } \\
\text { damage } \\
(n=30897)\end{array}$ & $\begin{array}{l}\text { Participants with } \\
\text { reduced renal function } \\
(n=2160)\end{array}$ & $\begin{array}{l}\text { Participants with } \\
\text { albuminuria }(n=4997)\end{array}$ & $\begin{array}{l}\text { Total } \\
(n=37533)\end{array}$ \\
\hline \multicolumn{5}{|c|}{ Demographic and clinical data } \\
\hline Age (years) & $73.52 \pm 5.32$ & $78.27 \pm 6.47$ & $73.62 \pm 5.46$ & $73.62 \pm 5.46$ \\
\hline Sex (Men) & $14985(48.50 \%)$ & $1001(46.34 \%)$ & $2447(48.97 \%)$ & $18172(48.42 \%)$ \\
\hline \multicolumn{5}{|c|}{ Physical measurements } \\
\hline $\begin{array}{l}\text { Body mass index } \\
\left(\mathrm{kg} / \mathrm{m}^{2}\right)\end{array}$ & $24.67 \pm 3.09$ & $24.94 \pm 3.20$ & $24.80 \pm 3.27$ & $24.69 \pm 3.12$ \\
\hline $\begin{array}{l}\text { Waist } \\
\text { circumference } \\
\text { (cm) }\end{array}$ & $81.49 \pm 7.76$ & $82.26 \pm 7.62$ & $81.67 \pm 7.89$ & $81.55 \pm 7.77$ \\
\hline $\begin{array}{l}\text { Systolic blood } \\
\text { pressure }(\mathrm{mmHg})\end{array}$ & $136.06 \pm 18.46$ & $139.54 \pm 20.74$ & $137.42 \pm 19.13$ & $136.37 \pm 18.66$ \\
\hline $\begin{array}{l}\text { Diastolic blood } \\
\text { pressure }(\mathrm{mmHg})\end{array}$ & $79.71 \pm 10.24$ & $80.58 \pm 11.08$ & $80.14 \pm 10.41$ & $79.78 \pm 10.30$ \\
\hline $\begin{array}{l}\text { Heart rate } \\
\text { (beats/min) }\end{array}$ & $75.08 \pm 8.94$ & $76.19 \pm 10.54$ & $75.75 \pm 9.58$ & $75.20 \pm 9.10$ \\
\hline \multicolumn{5}{|l|}{ Laboratory data } \\
\hline $\begin{array}{l}\text { Total cholesterol } \\
(\mathrm{mg} / \mathrm{dL})\end{array}$ & $200.70 \pm 38.94$ & $200.89 \pm 43.86$ & $201.51 \pm 42.12$ & $200.79 \pm 39.50$ \\
\hline $\begin{array}{l}\text { Triglycerides } \\
(\mathrm{mg} / \mathrm{dL})\end{array}$ & $137.50 \pm 98.16$ & $159.76 \pm 113.87$ & $142.61 \pm 113.77$ & $138.97 \pm 100.65$ \\
\hline $\begin{array}{l}\text { ALT (U/L; median } \\
\text { [IQR]) }\end{array}$ & $17.90(13.80 \sim 24.20)$ & $16.50(12.80 \sim 23.00)$ & $18.00(13.70 \sim 24.70)$ & $17.90(13.74 \sim 24.20)$ \\
\hline FBG (mg/dl) & $96.79 \pm 32.36$ & $102.92 \pm 41.93$ & $106.58 \pm 46.43$ & $98.28 \pm 34.99$ \\
\hline Creatinine $(\mathrm{mg} / \mathrm{dL})$ & $0.75 \pm 0.16$ & $1.29 \pm 0.59$ & $0.78 \pm 0.42$ & $0.77 \pm 0.24$ \\
\hline $\begin{array}{l}\text { eGFR } \\
\left(\mathrm{mL} / \mathrm{min} / 1.73 \mathrm{~m}^{2}\right)\end{array}$ & $85.84 \pm 9.60$ & $49.55 \pm 10.10$ & $84.75 \pm 17.26$ & $84.22 \pm 12.87$ \\
\hline WBC (*10^9/L) & $5.97 \pm 2.06$ & $6.26 \pm 2.05$ & $6.25 \pm 2.34$ & $6.01 \pm 2.10$ \\
\hline Hemoglobin (g/L) & $133.19 \pm 17.12$ & $128.42 \pm 19.91$ & $135.87 \pm 19.31$ & $133.27 \pm 17.58$ \\
\hline Platelet $\left(* 10^{\wedge} 9 / \mathrm{L}\right)$ & $172.02 \pm 54.52$ & $172.87 \pm 57.71$ & $179.18 \pm 60.99$ & $172.96 \pm 55.55$ \\
\hline
\end{tabular}

Data are $n(\%)$ or mean $( \pm S D), 521$ participants with reduced renal function had proteinuria. ALT was presented as median with interquartile range (IQR), because of non-normally distributed. 34457 participants completed hemoglobin, WBC and platelet examination. eGFR=estimated glomerular filtration rate. $W B C=$ white blood cell. $F B G=$ fasting blood glucose. $A L T=a l a n i n e$ aminotransferase.

Table 30General Characteristics of Study Participants according to indicators of kidney damage 


\begin{tabular}{|c|c|c|c|c|c|c|c|c|}
\hline & \multicolumn{8}{|c|}{ Participants with Chronic Kidney Disease } \\
\hline & $\begin{array}{l}\text { Prevalence } \\
n(\%)\end{array}$ & $\begin{array}{l}P \\
\text { Value }\end{array}$ & $\begin{array}{l}\text { OR } \\
(95 \% \mathrm{Cl})\end{array}$ & $\begin{array}{l}P \\
\text { Value }\end{array}$ & $\begin{array}{l}\mathrm{OR}^{\mathrm{a}} \\
(95 \% \mathrm{Cl})\end{array}$ & $\begin{array}{l}P \\
\text { Value }\end{array}$ & $\begin{array}{l}\mathrm{OR}^{\mathrm{b}} \\
(95 \% \mathrm{Cl})\end{array}$ & $\begin{array}{l}P \\
\text { Value }\end{array}$ \\
\hline \multicolumn{9}{|l|}{ Sex } \\
\hline Female & $\begin{array}{l}3449 \\
(17.8)\end{array}$ & NS & Ref & & - & & - & \\
\hline Male & $\begin{array}{l}3187 \\
(17.5)\end{array}$ & & 0.981 & NS & - & & - & \\
\hline \multicolumn{9}{|l|}{ Age } \\
\hline $65 \sim 69$ & $\begin{array}{l}1430 \\
(15.1)\end{array}$ & $<0.001$ & Ref & & - & & Ref & \\
\hline 70 74 & $\begin{array}{l}2290 \\
(16.0)\end{array}$ & & $\begin{array}{l}1.077 \\
(1.002 \sim 1.157)\end{array}$ & 0.043 & - & & $1.075(0.999 \sim 1.156)$ & 0.052 \\
\hline 75 79 & $\begin{array}{l}1364 \\
(18.0)\end{array}$ & & $\begin{array}{l}1.234 \\
(1.138 \sim 1.339)\end{array}$ & $<0.001$ & - & & $1.239(1.141 \sim 1.345)$ & $<0.001$ \\
\hline $80 \sim 84$ & $\begin{array}{l}1007 \\
(23.4)\end{array}$ & & $\begin{array}{l}1.718 \\
(1.570 \sim 1.881)\end{array}$ & $<0.001$ & - & & $1.748(1.595 \sim 1.917)$ & $<0.001$ \\
\hline$\geq 85$ & $545(29.3)$ & & $\begin{array}{l}2.338 \\
(2.085 \sim 2.622)\end{array}$ & $<0.001$ & - & & $2.401(2.135 \sim 2.701)$ & $<0.001$ \\
\hline \multicolumn{9}{|l|}{ BMI } \\
\hline $18.5 \sim 23.9$ & $\begin{array}{l}2652 \\
(17.1)\end{array}$ & 0.013 & Ref & & Ref & & Ref & \\
\hline$<18.5$ & $114(18.5)$ & & $\begin{array}{l}1.096 \\
(0.891 \sim 1.349)\end{array}$ & NS & $\begin{array}{l}1.030 \\
(0.836 \sim 1.270)\end{array}$ & NS & $1.091(0.884 \sim 1.347)$ & NS \\
\hline $24.0 \sim 27.9$ & $\begin{array}{l}2790 \\
(17.6)\end{array}$ & & $\begin{array}{l}1.035 \\
(0.976 \sim 1.097)\end{array}$ & NS & $\begin{array}{l}1.082 \\
(1.020 \sim 1.148)\end{array}$ & 0.009 & $1.008(0.948 \sim 1.072)$ & NS \\
\hline$\geq 28$ & $984(19.1)$ & & $\begin{array}{l}1.144 \\
(1.055 \sim 1.240)\end{array}$ & $<0.001$ & $\begin{array}{l}1.218 \\
(1.122 \sim 1.323)\end{array}$ & $<0.001$ & $1.058(0.968 \sim 1.157)$ & NS \\
\hline \multicolumn{9}{|c|}{ Central obesity } \\
\hline No & $\begin{array}{l}4008 \\
(17.2)\end{array}$ & 0.002 & Ref & 0.002 & Ref & & Ref & \\
\hline Yes & $\begin{array}{l}2616 \\
(18.5)\end{array}$ & & $\begin{array}{l}1.091 \\
(1.033 \sim 1.152)\end{array}$ & & $\begin{array}{l}1.134 \\
(1.065 \sim 1.208)\end{array}$ & $<0.001$ & $1.027(0.968 \sim 1.090)$ & NS \\
\hline \multicolumn{9}{|c|}{ Hypertension } \\
\hline No & $529(15.3)$ & $<0.001$ & Ref & & Ref & & Ref & \\
\hline Pre-HTN & $\begin{array}{l}3320 \\
(17.0)\end{array}$ & & $\begin{array}{l}1.134 \\
(1.026 \sim 1.253)\end{array}$ & 0.013 & $\begin{array}{l}1.123 \\
(1.016 \sim 1.241)\end{array}$ & 0.023 & $1.093(0.987 \sim 1.210)$ & 0.088 \\
\hline HTN & $\begin{array}{l}2776 \\
(19.1)\end{array}$ & & $\begin{array}{l}1.308 \\
(1.181 \sim 1.447)\end{array}$ & $<0.001$ & $\begin{array}{l}1.297 \\
(1.171 \sim 1.436)\end{array}$ & $<0.001$ & $1.204(1.084 \sim 1.338)$ & 0.001 \\
\hline \multicolumn{9}{|l|}{ FBG } \\
\hline$<100$ & $\begin{array}{l}4416 \\
(16.1)\end{array}$ & $<0.001$ & Ref & & Ref & & Ref & \\
\hline $100 \sim 125$ & $\begin{array}{l}1164 \\
(19.0)\end{array}$ & & $\begin{array}{l}1.216 \\
(1.132 \sim 1.306)\end{array}$ & $<0.001$ & $\begin{array}{l}1.224 \\
(1.139 \sim 1.315)\end{array}$ & $<0.001$ & $1.172(1.089 \sim 1.262)$ & $<0.001$ \\
\hline
\end{tabular}




\begin{tabular}{|c|c|c|c|c|c|c|c|c|}
\hline$\geq 126$ & $\begin{array}{l}1052 \\
(26.3)\end{array}$ & & $\begin{array}{l}1.85 \\
(1.712 \sim 1.999)\end{array}$ & $<0.001$ & $\begin{array}{l}1.875 \\
(1.734 \sim 2.207)\end{array}$ & $<0.001$ & $1.766(1.630 \sim 1.914)$ & $<0.001$ \\
\hline \multicolumn{9}{|c|}{ Triglyceride levels (mmol/L) } \\
\hline$<2.26$ & $\begin{array}{l}5432 \\
(17.1)\end{array}$ & $<0.001$ & Ref & & Ref & & Ref & \\
\hline$\geq 2.26$ & $\begin{array}{l}1202 \\
(20.8)\end{array}$ & & $\begin{array}{l}1.267 \\
(1.182 \sim 1.359)\end{array}$ & $<0.001$ & $\begin{array}{l}1.308 \\
(1.218 \sim 1.404)\end{array}$ & $<0.001$ & $1.159(1.076 \sim 1.248)$ & $<0.001$ \\
\hline \multicolumn{9}{|c|}{ Total cholesterol level (mmol/L) } \\
\hline$<6.21$ & $\begin{array}{l}5551 \\
(17.4)\end{array}$ & 0.001 & Ref & & Ref & & Ref & \\
\hline$\geq 6.21$ & $\begin{array}{l}1083 \\
(19.3)\end{array}$ & & $\begin{array}{l}1.136 \\
(1.056 \sim 1.221)\end{array}$ & 0.001 & $\begin{array}{l}1.147 \\
(1.066 \sim 1.235)\end{array}$ & $<0.001$ & $1.067(0.989 \sim 1.150)$ & 0.092 \\
\hline
\end{tabular}

${ }^{a}$ adjusted for age and sex; ${ }^{b}$ multivariate analysis.

Chronic kidney disease was defined as eGFR $<60 \mathrm{~mL} / \mathrm{min} / 1.73 \mathrm{~m}^{2}$ or proteinuria.

Abbreviation: FBG, fasting blood glucose; HTN, hypertension; BMI, body mass index; Ref, reference group; NS, not statistically significant, therefore not included in the final model; OR, odds ratio; $95 \% \mathrm{Cl}, 95 \%$ confidence interval.

\section{Figures}

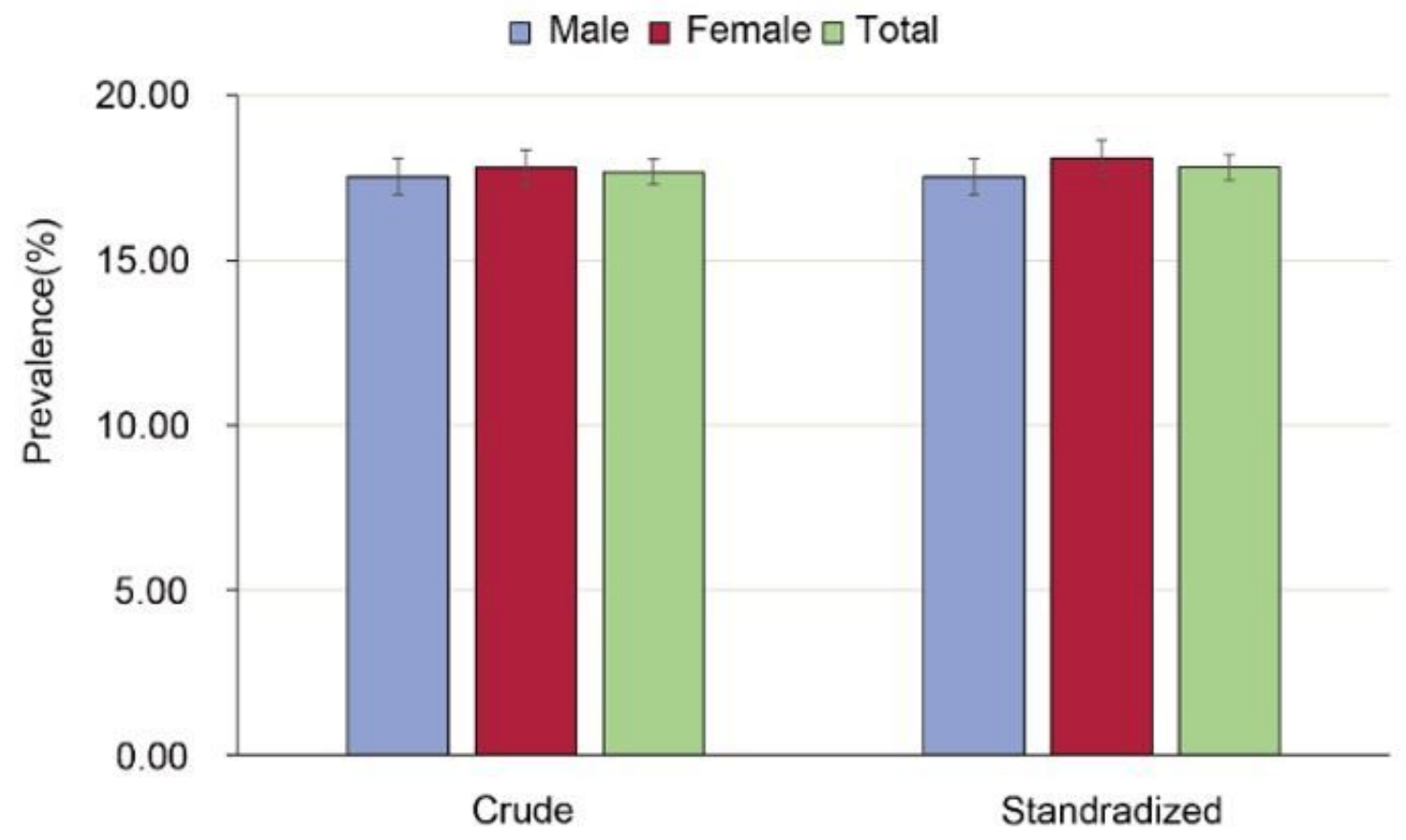

Figure 1

Crude and Standardized Prevalence of chronic kidney disease in older Adults Aged 65 Years or Older in Binhai in 2018. 


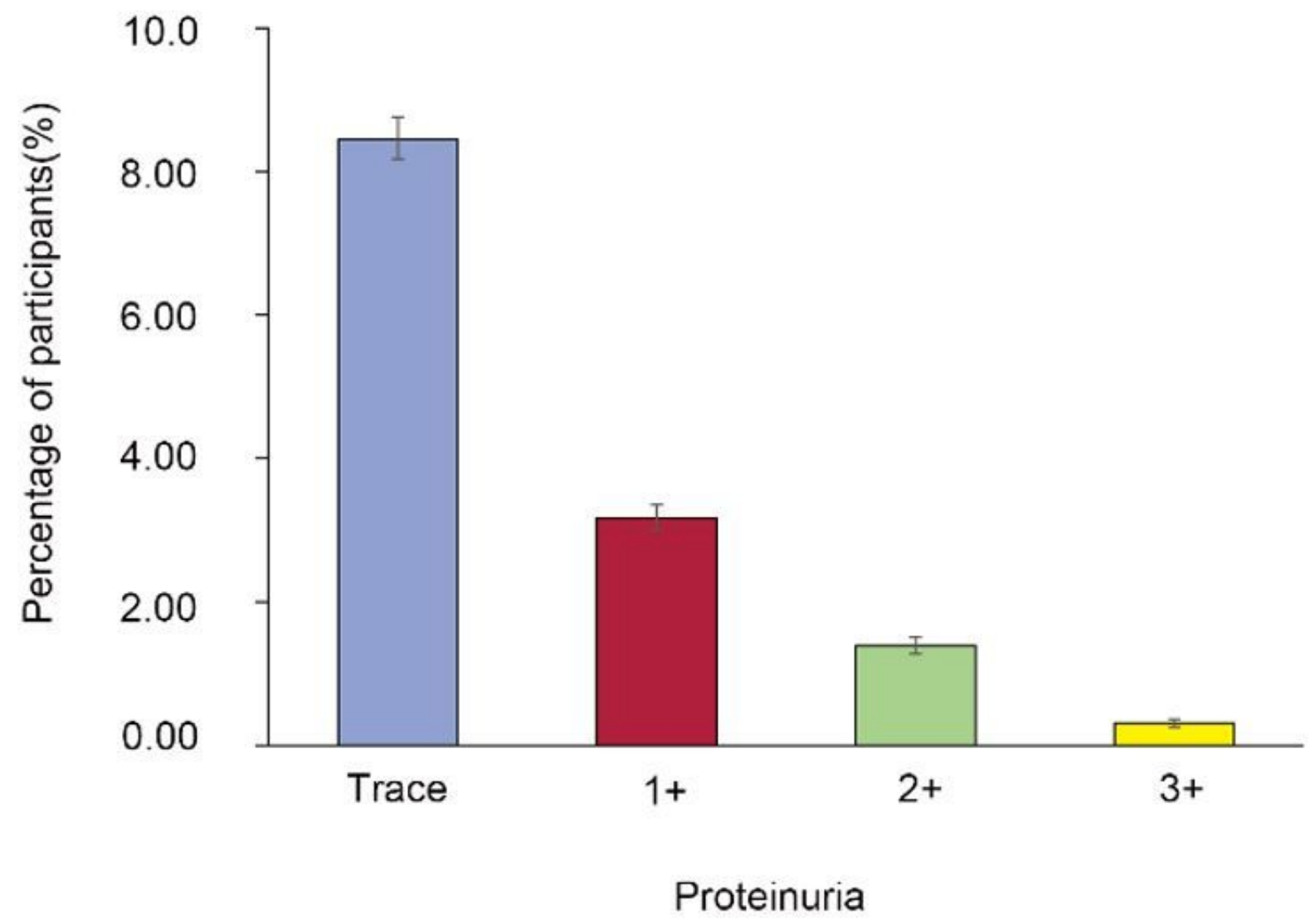

Figure 2

Distribution of proteinuria for participants in this study. 


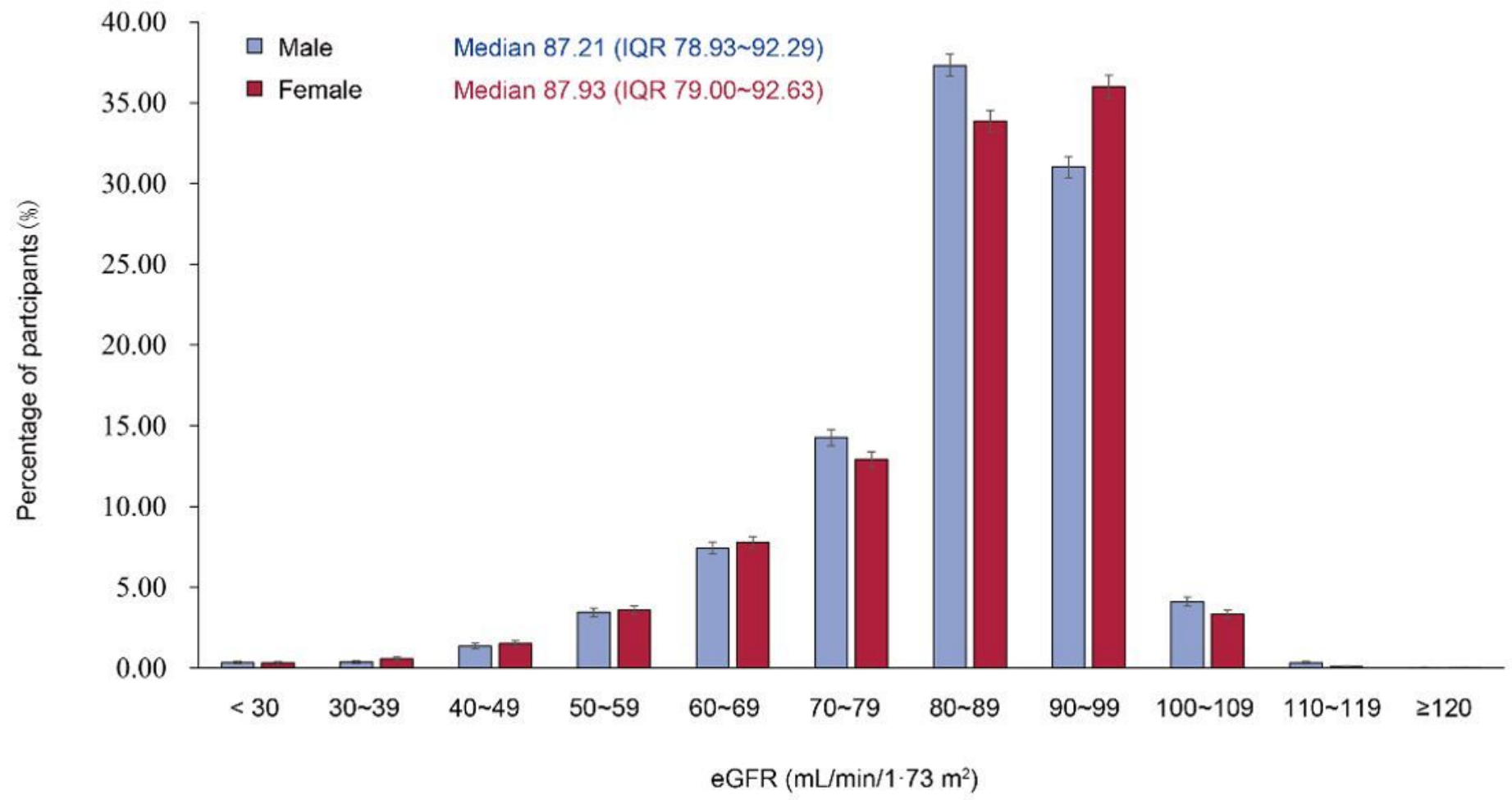

Figure 3

Distribution of kidney function by sex for participants in this study. 

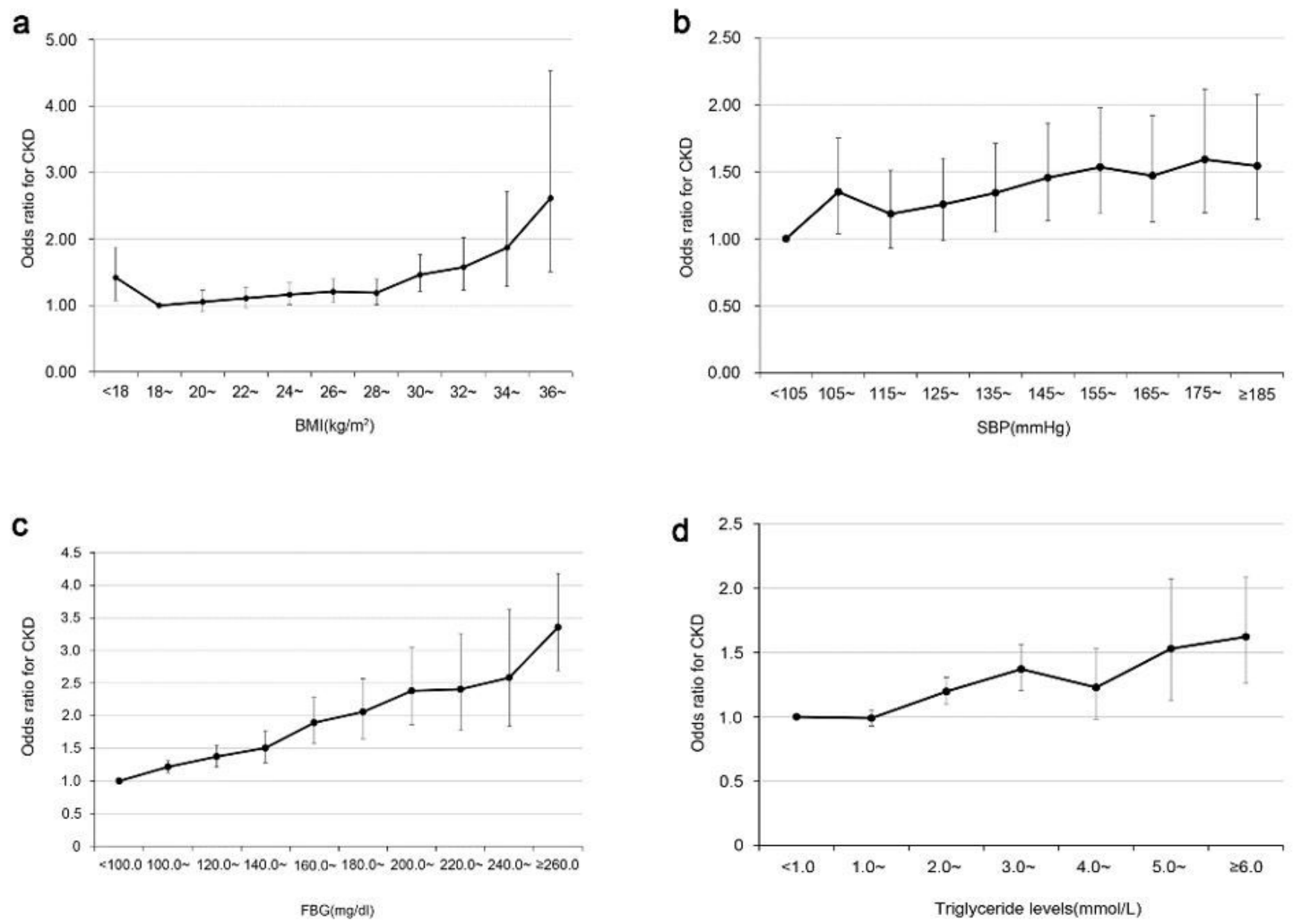

Figure 4

Odds Ratio for CKD associated with metabolic factors among older Adults in this study.

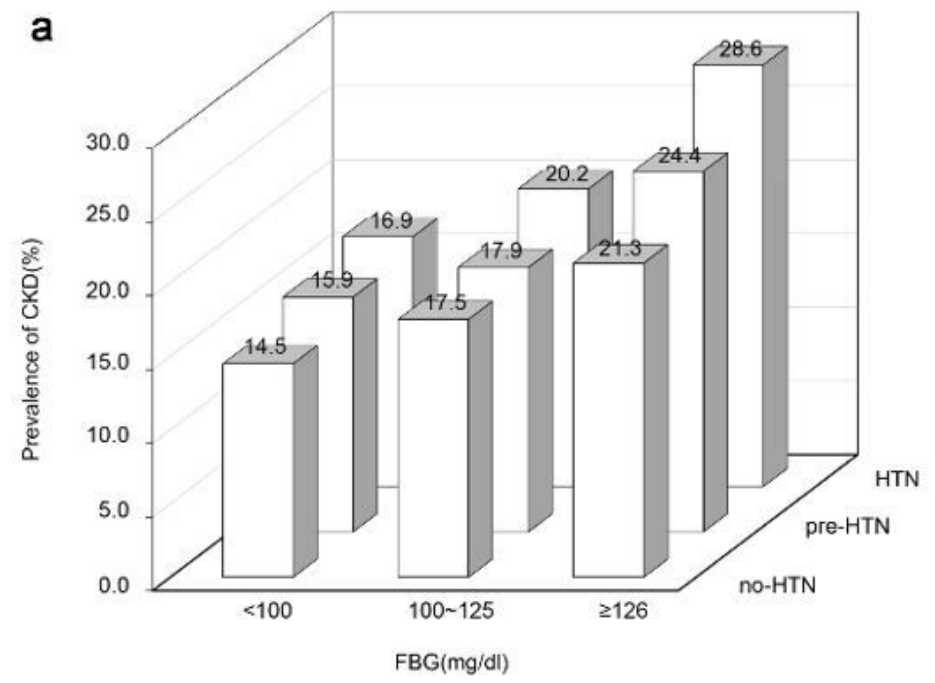

b

\begin{tabular}{|c|c|c|c|c|}
\cline { 3 - 5 } \multicolumn{2}{c|}{} & \multicolumn{3}{c|}{ Classification of Hypertension } \\
\cline { 3 - 5 } \multicolumn{2}{c|}{} & no-HTN & pre-HTN & HTN \\
\hline \multirow{2}{*}{$\begin{array}{c}\text { FBG } \\
(\mathrm{mg} / \mathrm{dl})\end{array}$} & $\mathbf{1 0 0}$ & 1 & 1.234 & 1.587 \\
\cline { 2 - 5 } & $\mathbf{1 0 0 ~ 1 2 5}$ & 1.103 & 1.279 & 1.900 \\
\cline { 2 - 5 } & $\geq 126$ & 1.185 & 1.485 & 2.372 \\
\hline
\end{tabular}

Figure 5 
The prevalence and Odds ratio for CKD associated with level of FBG and classification of Hypertension in the elderly in Binhai.

Page 16/16 